\title{
THE EFFECTIVENESS OF BULLYING CURRICULUM FOR PREVENTION AND MANAGEMENT OF BULLYING IN SCHOOL-AGED CHILDREN
}

\author{
Nur Eni Lestari, Yeni Koto \\ Sekolah Tinggi Ilmu Kesehatan Indonesia Maju \\ Email: nurenilestari@gmail.com
}

\begin{abstract}
Introduction: Bullying is still a problem and continues to increase especially in school-aged children. If cases of bullying do not get any immediate treatment, it will cause various problems from psychological, psychosomatic, social, academic issues, and even present a risk of suicide. The purpose of this study was to determine the effectiveness of bullying curriculum for prevention and management of bullying in school-aged children. Methods: The study used a quantitative study method with a quasi-experimental of pre and post-test without control group design. The population of this study was students of grade-five in one of primary school in Jakarta. The samples of this study used total sampling consisting of 30 respondents. The instrument of this study used the instrument of bullying that was modified by the researchers and has passed the validity and reliability test. The analysis of this study used McNemar test. Results: The result of this study shows that there were bullying incidents occurred for as much as $100 \%$ before the intervention and as much as $60 \%$ after the intervention. The result of bivariate test of this study shows the value of $p=0.000$. Conclusions: The implementation of curriculum of bullying is effective for prevention and management of bullying in school-aged children.
\end{abstract}

Keywords: bullying; curriculum; school; school-aged children

\section{INTRODUCTION}

Bullying is the most common form of aggressive behavior which characterized by physical, verbal, and social violence that can cause harm, power imbalance between the perpetrator and the victim, and is repeated overtime (Mucherah, Finch, White, \& Thomas, 2018; Olweus, 2005). Bullying often occurs in schools and continues to increase. UNICEF reported in 2015 that $40 \%$ of children experienced bullying in school (Arseneault et al., 2006; Mundy et al., 2017). In Indonesia, there are more than 26,000 cases of bullying happen in children and this number increase at a rate of $16.3 \%$ every year (Setyawan, 2017).

Bullying is caused by a complex reason and this includes multidimensional problems that are connected by various factors (Murray-harvey, 2010; Shaheen, Hammad, Haourani, \& Nassar, 2018). Several studies has shown that children who come from lower socioeconomic status face a high risk of bullying (Fu, Land, \& Lamb, 2013; Jansen et al., 2012). In China, aside from sociodemographic factors, academic achievement, and gender differences, bullying is also influenced by parenting style, teacher-and-

student relationship, social media, and individual characteristics (Huang, Hong, \& Espelage, 2013).

The negative impact of bullying shown in the perpetrators including a symptom of emotional disturbance and psychological trauma (Sarzosa \& Urzúa, 2015). Meanwhile, the negative impact shown in the victims shows an even broader scope including health problem, both psychological and psychosomatic, social, and academic problems (Karatas \& Ozturk, 2011; Oliveira, Menezes, Irffi, \& Oliveira, 2017). Short-term problems experienced by victims of bullying are expressions of anger, disturbed sleep pattern, psychosomatic problems like abdominal area pain and headache (Fekkes, 2005; Gini \& Pozzoli, 2013; Rigby, 2007; van Geel, Goemans, \& Vedder, 2015). Moreover, the victims may also face chronic stress which triggers the problem of falling academic achievement, feeling of loneliness, unhappiness, fatigue, and anxiety that will possibly lead to severe depression (Fu et al., 2013; Kim, 2005) and even present a risk of suicide (Verwest, F. Sorel, N. Buitelaar, 
2013).

The efforts of prevention and

management of bullying have been carried out numerous times but those still cannot stop bullying incidents of happening. Previous researches proposed that an alternative strategy is the use of police officers in school, best known as School Resource Officers (SROs). This policy, police officers in school management, is proven to be effective in preventing bullying (Devlin, Santos, \& Gottfredson, 2018). Other researches inform that curriculum of bullying can improve social competencies, skills, and strategies of nursing students in handling bullying. Based on the above, a research is required to be carried out as an effort of prevention and management of bullying in school-aged children with the implementation of curriculum of bullying (Sidhu \& Park, 2018). The purpose of this study was to determine the effectiveness of bullying curriculum for prevention and management of bullying in school-aged children.

\section{METHODS}

The study used a quantitative study method with a quasi-experimental of pre and post-test without control group design. The population of this study was students of gradefive in one of primary school in Jakarta. The samples of this study used total sampling consisting of 30 respondents. The instrument of this study used the instrument of bullying that was modified by the researchers and has passed the validity and reliability test. The

analysis of this study used McNemar test because the type of data used categorical data.

The flow of this study are: (1)

conducting preliminary study and data collection by reviewing literatures that related to bullying, planning a study implementation including activities to formulate study activity design, study objectives, study outcomes, study steps, and listing stakeholders to be involved in to prevent and manage bullying; (2) conducting study implementation consists of

preparation of initial curriculum development including compiling curriculum content, determining curriculum design, developing curriculum draft consist of learning plan related to bullying. Afterwards, expert test which results are used as a basis for curriculum draft improvement. The contents of the curriculum are: (1) developed value; (2) developed standards; (3) implementation includes material delivered consist of the definition, causes, forms, types, impacts, and management of bullying; (4) competency. The time allocation is 25 minutes per week. This study was approved by the ethics committee of the Sekolah Tinggi Ilmu Kesehatan Indonesia Maju with the ethical clearance statement that it has passed ethical procedure and were declared eligible to be implemented with the number 2215/SPs/K/RE/STIKIM/VII/2019.

\section{RESULTS}

The results of this study described, before the bullying curriculum was implemented, there were 0 the perpetrators, 2 the victims, and 28 both perpetrators and victims. Meanwhile, after the curriculum was implemented, there were 0 the perpetrators, 11 the victims, 7 both perpetrators and victims, and 12 no bullying incidents.

Table 1: The Effectiveness of Bullying Curriculum for Prevention and Management of Bullying in School-Aged Children

\begin{tabular}{|c|c|c|}
\hline$\frac{\text { Bullying incidents }}{\text { Pernetrators }}$ & $\begin{array}{l}\text { No } \\
\text { bullving }\end{array}$ & Total \\
\hline
\end{tabular}

formulating and designing the instrument of bullying curriculum as an effort 
Jurnal INJEC Vol. 4 No. 2 December 2019: 99-104

\begin{tabular}{lllcc}
\hline Before & 0 & 0 & 30 & 0.00 \\
& & & & 0
\end{tabular}

$\begin{array}{llll}\text { After } & 0 & 12 & 30\end{array}$

Based on table 1, it shows that all the 30 respondents in this study has experienced bullying before the bullying curriculum was implemented (100\%). Meanwhile, after the 
curriculum was implemented, the bullying incidents decreased to only 12 students (40\%).

\section{DISCUSSIONS}

The study result shows that before the curriculum was implemented, 2 respondents became the victims and as many as 28 respondents became both the perpetrators and the victims. Meanwhile, after the curriculum was implemented, 11 respondents became the victims of bullying, 7 respondents became both the perpetrators and the victims, and the rest 12 respondents didn't experience bullying. Bullying is an aggressive behavior that combines three core elements, namely the intention to harm, to be repetitive, and an imbalance of power between the perpetrator and the victim (CDC, 2014; Mucherah et al., 2018; Olweus, 2005).. Perpetrators are individuals who intend to harm the victims through their actions over a long period of time and carry out their actions repeatedly. Whereas victims are usually weaker than certain perpetrators or group of perpetrators and fee that he or she does not have ability to selfdefense. This occurs because of an imbalance in physical or social power (Eleni, 2014; Gaffney, Ttofi, \& Farrington, 2018).

This study describes that there has been a reduction in the incidence of bullying after the implementation of bullying curriculum for as many as 12 respondents or equals to $40 \%$. This indicates that the implementation of bullying curriculum is effective for prevention and management of bullying in school-aged children. The contents of the curriculum are developed value, developed standards, implementation includes material delivered consist of the definition, causes, forms, types, impacts, and management of bullying and competency. The time allocation is 25 minutes per week. This is in line with a study conducted in Canada which recommends that prevention of bullying is very important to be carried out by empowering nursing students to develop a curriculum of bullying in the effort to prevent bullying (Juniarti, Sari, \& Yani, 2017; Sidhu \& Park, 2018).

The bullying framework is adapted from the Bronfenbrenner ecological model as was done with the NASEM bullying report. There are four layers of bullying; namely social stigma, structure, interpersonal, and individual actors. Social stigma consists of religion, race, sexual orientation, socially devaluated characteristics, gender identity, immigration, disability, and obesity. The structure layer consists of bullying of national origin, school, class, religious organization, and clubs. The interpersonal layer is bullying related to individuals, parents, teachers, coaches, and peers. The layers of individual actors consist of social domination, orientation, stereotypes, and prejudice. Stigma-based bullying includes general, verbal, physical, relational, property damage, and cyberbullying. While specific stigma includes homophobic epithets, sexual harassment, and racial slurs. The consequences that will occur if bullying occurs is a decrease in academic achievement and physical and mental health (Earnshaw et al., 2018).

Prevention and management of bullying is essential especially in schools as bullying can cause various problems including related to academic achievement and attendance. Many strategies can be used in handling this problem such as the role of teachers in giving guidance and counseling (Kim, 2005; Richard J. Hunter \& Lozada, 2012; Ugorji \& Morand-reid, 2014). Other consequences that can arise from bullying include health problem from psychological, psychosocial, and social problem (Karatas \& Ozturk, 2011; Oliveira et al., 2017). Shortterm problems experienced by victims of bullying are expressions of anger, disturbed sleep pattern, psychosomatic problems like abdominal area pain and headache (Fekkes, 2005; Gini \& Pozzoli, 2013; Rigby, 2007; van Geel et al., 2015). Moreover, the victims may also face chronic stress which triggers the problem of falling academic achievement, 
feeling of loneliness, unhappiness, fatigue, and anxiety that will possibly lead to severe depression (Fu et al., 2013; Kim, 2005)and even present a risk of suicide (Verwest, F. Sorel, N. Buitelaar, 2013).The limitation of this study is that the number of curriculum forwarders is not in accordance with the predetermined number of 18 times in one semester in accordance with the effective weeks of teaching and learning activities. This study only implemented 6 meetings due to time limitation. This causes only a $40 \%$ reduction in the incidence of bullying.

\section{CONCLUSIONS}

The implementation of curriculum of bullying is effective for prevention and management of bullying in school-aged children. Curriculum of bullying can be implemented in primary schools as an effort to prevent and manage bullying cases in schoolaged children.

\section{ACKNOWLEDGMENT}

The researchers would like to thank The Ministry of Research, Technology and the Republic of Indonesia's National Innovation Research Agency.

\section{REFERENCES}

Arseneault, L., Walsh, E., Trzesniewski, K., Newcombe, R., Caspi, A., \& Moffitt, T. E. (2006). Bullying Victimization Uniquely Contributes to Adjustment Problems in Young Children: A Nationally Representative Cohort Study. Pediatrics, 118(1), 130-138. https://doi.org/10.1542/peds.2005-2388

CDC. (2014). Center of Disease Control and Prevention. Retrieved from https://www.cdc.gov/hai/surveillance/ind ex.html

Devlin, D. N., Santos, M. R., \& Gottfredson, D. C. (2018). An evaluation of police officers in schools as a bullying intervention. Evaluation and Program
Planning, $\quad$ 71(July), 12-21. https://doi.org/10.1016/j.evalprogplan.20 18.07.004

Earnshaw, V. A., Reisner, S. L., Menino, D. D., Poteat, V. P., Bogart, L. M., Barnes, T. N., \& Schuster, M. A. (2018). Stigmabased bullying interventions: A systematic review. Developmental Review, 48(January), 178-200. https://doi.org/10.1016/j.dr.2018.02.001

Eleni, P. (2014). School Bullying: The Phenomenon, the Prevention and the Intervention. Procedia - Social and Behavioral Sciences, 152, 268-271. https://doi.org/10.1016/j.sbspro.2014.09. 193

Fekkes, M. (2005). Bullying among elementary school children. Netherlands: De Bink.

Fu, Q., Land, K. C., \& Lamb, V. L. (2013). Bullying victimization, socioeconomic status and behavioral characteristics of 12th graders in the United States, 1989 to 2009: Repetitive trends and persistent risk differentials. Child Indicators Research, 6(1), 1-21. https://doi.org/10.1007/s12187-0129152-8

Gaffney, H., Ttofi, M. M., \& Farrington, D. P. (2018). Evaluating the effectiveness of school-bullying prevention programs: An updated meta-analytical review. Aggression and Violent Behavior, \#pagerange\#. https://doi.org/10.1016/j.avb.2018.07.001

Gini, G., \& Pozzoli, T. (2013). Bullied Children and Psychosomatic Problems: A Metaanalysis. Pediatrics, 132(4), 720-729. https://doi.org/10.1542/peds.2013-0614

Huang, H., Hong, J. S., \& Espelage, D. L. (2013). Understanding Factors Associated with Bullying and Peer Victimization in Chinese Schools Within Ecological Contexts. Journal of Child and Family Studies, 22(7), 881-892. https://doi.org/10.1007/s10826-0129647-4 
Jansen, P. W., Verlinden, M., Berkel, A. D., Mieloo, C., van der Ende, J., Veenstra, R., ... Tiemeier, H. (2012). Prevalence of bullying and victimization among children in early elementary school: Do family and school neighbourhood socioeconomic status matter? $B M C$ Public Health, 12(1), 494.

https://doi.org/10.1186/1471-2458-12494

Juniarti, N., Sari, S. P., \& Yani, D. I. (2017). Analysis and evaluation of implementation of undergraduate nursing curricullum for family nursing in West Jawa. Indonesian Nursing Journal of Education and Clinic (Injec), 1(2), 103. https://doi.org/10.24990/injec.v1i2.119

Karatas, H., \& Ozturk, C. (2011). Relationship between bullying and health problems in primary school children. Asian Nursing Research, 5(2), 81-87. https://doi.org/10.1016/S19761317(11)60016-9

Kim, Y. S. (2005). School Bullying and Suicidal Risk in Korean Middle School Students. Pediatrics, 115(2), 357-363. https://doi.org/10.1542/peds.2004-0902

Mucherah, W., Finch, H., White, T., \& Thomas, K. (2018). The relationship of school climate, teacher defending and friends on students' perceptions of bullying in high school. Journal of Adolescence, 62(November 2017), 128-

139.

https://doi.org/10.1016/j.adolescence.201 7.11.012

Mundy, L. K., Canterford, L., Kosola, S., Degenhardt, L., Allen, N. B., \& Patton, G. C. (2017). Peer Victimization and Academic Performance in Primary School Children. Academic Pediatrics, 17(8), 830-836. https://doi.org/10.1016/j.acap.2017.06.01 2

Murray-harvey, R. (2010). Academic achievement, psychological health and well-being at school. Educational \& Child Psychology, 27(1), 104-115.
Oliveira, F. R., Menezes, T. A. de, Irffi, G. D., \& Oliveira, G. R. (2017). Bullying Effect on Students' Performance. EconomiA, 19,

$57-73$.

https://doi.org/10.1016/j.econ.2017.10.00 1

Olweus, D. (2005). A useful evaluation design, and effects of the Olweus Bullying Prevention Program. Psychology, Crime and Law, 11(4), 389-402. https://doi.org/10.1080/10683160500255 471

Richard J. Hunter, J., \& Lozada, H. R. (2012). Effects of Bullying in Schools: The Teachers' Perspectives. Journal of Society and Communication, 2012(October). Retrieved from http://journalofsocietyandcommunication .com/index.php/jsc/article/viewFile/44/1 2

Rigby, K. (2007). Bullying in Schools: and what to do about it. National Library of Australia, $\quad 22, \quad 1-330$. https://doi.org/10.2753/EUE10564934220192

Sarzosa, M., \& Urzúa, S. (2015). Bullying among adolescents: The role of cognitive and non-cognitive skills. National Institutes of Health, 1-59. https://doi.org/10.3386/w21631

Setyawan, D. (2017). KPAI Terima Aduan 26 Ribu Kasus Bully Selama 2011-2017.

Detik News. Retrieved from http://www.kpai.go.id/berita/kpai-terimaaduan-26-ribu-kasus-bully-selama-20112017

Shaheen, A. M., Hammad, S., Haourani, E. M., \& Nassar, O. S. (2018). Factors Affecting Jordanian School Adolescents' Experience of Being Bullied. Journal of Pediatric Nursing, 38, e66-e71. https://doi.org/10.1016/j.pedn.2017.09.00 3

Sidhu, S., \& Park, T. (2018). Nursing curriculum and bullying: An integrative literature review. Nurse Education Today, 65, 169-176. https://doi.org/10.1016/j.nedt.2018.03.00 
Jurnal INJEC Vol. 4 No. 2 December 2019: 99-104

5

Ugorji, J., \& Morand-reid, H. (2014). Impact of an Urban High School Conflict Resolution Program on Peer Mediators: A Single Case Study. Walden University. https://doi.org/UMI : 3257958

van Geel, M., Goemans, A., \& Vedder, P. H. (2015). The relation between peer victimization and sleeping problems: A meta-analysis. Sleep Medicine Reviews,

27 ,

89-95.

https://doi.org/10.1016/j.smrv.2015.05.0

04

Verwest, F. Sorel, N. Buitelaar, E. (2013). Psychosocial Health Among Young Victims and Offenders of Direct and Indirect Bullying. Radboud Repository, 144. https://doi.org/10.1063/1.3033202 